\title{
Spatial and temporal variability of surface chlorophyll- $a$ in the Gulf of Tomini, Sulawesi, Indonesia
}

\author{
QURNIA WULAN SARI ${ }^{1, \bullet}$, EKO SISWANTO $^{2}$, DEDI SETIABUDIDAYA ${ }^{3}$, INDRA YUSTIAN $^{4}$, ISKHAQ ISKANDAR $^{3, \bullet \bullet}$ \\ ${ }^{1}$ School of Environmental Science, Universitas Sriwijaya. Palembang 30139, South Sumatra, Indonesia. `email: qurnia.wulansari@gmail.com \\ ${ }^{2}$ Department of Environmental Geochemical Cycle, Research, and Development Center for Global Change (concurrent), Japan, Agency for Marine-Earth \\ Science, and Technology 3173-25, Showa-machi, Kanazawa-ku, Yokohama, Kanagawa, 236-0001, Japan \\ ${ }^{3}$ Department of Physics, Faculty of Mathematics, and Natural Sciences, Universitas Sriwijaya. Inderalaya 30662, South Sumatra, Indonesia. ${ }^{\vee}$ email: \\ iskhaq@mipa.unsri.ac.id. \\ ${ }^{4}$ Department of Biology, Faculty of Mathematics, and Natural Sciences, Universitas Sriwijaya. Inderalaya 30662, South Sumatra, Indonesia
}

Manuscript received: 20 February 2018. Revision accepted: 11 April 2018.

\begin{abstract}
Sari QW, Siswanto E, Setiabudidaya D, Yustian I, Iskandar I. 2018. Spatial and temporal variability of surface chlorophyll-a in the Gulf of Tomini, Sulawesi, Indonesia. Biodiversitas 19: 793-801. The Gulf of Tomini (GoT) is mostly influenced by seasonal and interannual events. So, the immensive aim of this study is to explore spatial and temporal variations of chlorophyll- $a$ (chl- $a$ ) and oceanographic parameters in the GoT under the influences of monsoonal winds, El Niño Southern Oscillation (ENSO), and Indian Ocean Dipole (IOD). The data were collected from the satellite imaging of chl- $a$ and sea and surface temperature (SST) as well as surface wind from the reanalysis data for a period of January 2003 to December 2015. Monthly variations of the chl- $a$ and SST in the GoT reveal chl- $a$ bloom in the center part to the mouth of the GoT during the southeast monsoon season (boreal summer). The chl- $a$ concentrations were relatively higher $\left(>0.1 \mathrm{mg} \mathrm{m}^{-3}\right)$ and distributed throughout most of the areas near the Maluku Sea. The SST in the middle of the GoT was relatively lower than that near the Maluku Sea (the eastern part of the GoT). On the other hand, during the northwest monsoon (boreal winter), the chl- $a$ concentration decreased $\left(<0.1 \mathrm{mg} \mathrm{m}^{-3}\right)$. During this season, the SST was relatively higher $\left(28-29^{\circ} \mathrm{C}\right)$ than that during the boreal summer $\left(27-26^{\circ} \mathrm{C}\right)$ and distributed uniformly. Meanwhile, on interannual timescale, the ENSO and IOD play important role in regulating chl- $a$ distribution in the GoT. High surface chl- $a$ concentration was observed during El Niño and/or positive IOD events. Enhanced surface chl- $a$ concentration during El Niño and/or positive IOD events was associated with the upward Ekman pumping induced by the southeasterly wind anomalies. The situation was reversed during the Niña and/or negative IOD events.
\end{abstract}

Keywords: Chlorophyll- $a$ bloom, Ekman pumping, ENSO, Gulf of Tomini, IOD

\section{INTRODUCTION}

Dynamics of the Indonesian water mass are influenced by various factors such as monsoonal wind system on the seasonal timescale and the El Niño-Southern Oscillation (ENSO) and Indian Ocean Dipole (IOD) event on the interannual timescale (Qu et al. 2005; Susanto et al. 2006). The seasonal climate is primarily shaped as a result of the Asia-Australia (AA) monsoon system, namely southeast monsoon (June-August) and northwest monsoon (December-February) (Susanto et al. 2006). The ENSO is a major mode of climate variability that takes place in the tropical Pacific Ocean (Trenberth 1997). Meanwhile, the IOD is a coupled ocean-atmosphere phenomenon in the tropical Indian Ocean that has strong impact on the Indian Ocean (Saji et al. 1999; Webster et al. 1999).

The Gulf of Tomini (GoT) is a semi-enclosed waters in the northern Indonesian with unique topography that marked by the geographic boundaries, the Maluku Sea in eastern of the GoT and the coastal lines in the western, northern, and southern (Widodo 2004; Setiawan and Habibi 2011), which is in close proximity to eastern pathway of the Indonesian Throughflow (ITF) (Figure 1). The eastern route of the ITF is through the Maluku Sea, which depends on the Mindanao Current and the current reflection in the southwestern boundary of the Pacific Ocean (Waworuntu et al. 2000). The ITF water through the Maluku Sea is generally carried out from the north of Pacific Ocean (Sprintall et al. 2014a; Sprintall and Revelard 2014b).The transport and circulation of the ITF show annual and interannual variability associated with monsoonal winds variation and ENSO event. It should be noted that the ITF transport is higher during the southeast monsoon than during the northeast monsoon (Ffield and Gordon 1996; Sprintall and Revelard 2014b). ITF has an important role in the health of marine ecosystem and it is a part of the global thermohaline conveyor belt (Godfrey 1996; Lee et al. 2002; Gordon 2005a).

The combination of the complex GoT topography, the seasonal variation of the monsoonal winds, the interannual forcing in the Pacific and Indian Ocean contribute to the transformation of water mass mixing. The water mass mixing has a positive impact on the quality of marine ecosystems that was hypothesized to mediate phytoplankton biomass. The phytoplankton biomass is a key indicator for upwelling regions associated with fishing grounds and mostly distinguished by the chl- $a$ concentration in upwelling waters. In addition, upwelling could also induce the nutrient source and the chl- $a$ concentration lift up to the surface waters. It should be noted that nutrient is 
strongly related to the part of the primary productivity component (Setiawan and Kawamura 2011).

In recent decades, the utilization of remote sensing had been significantly increased for examining the spatial and temporal variability of biological-physical components. Previous studies have shown the utilization of the satellite data. The chl- $a$ tends more intense during the boreal summer (the southeast monsoon) and becomes even higher during the El Niño event (Asanuma 2003; Susanto et al. 2006). Besides ENSO, IOD (Indian Ocean Dipole) has been noticed as a great force of coupled ocean-atmosphere interaction. In addition, Iskandar et al. discusses the impact of the 2006 PIOD event on the surface distribution of chl- $a$ in the Southeastern Tropical Indian Ocean (SETIO) region (Iskandar et al. 2009; 2010). Moreover, Habibi et al. observed that an intensifying of the chl- $a$ concentration was begun in May and attained its maximum in August (1.1 mg $\mathrm{m}-3$ ) before it declined in September along south of Sulawesi island waters. The intensification of chl- $a$ concentration concurred with the southeasterly monsoon winds that form the coastal upwelling formation along the south of Sulawesi Island. In addition, Wirasatriya et al. (2017) focused the observation on the impact of ENSO event (El Niño and La Niña) on variability of chl- $a$ and SST in the Maluku Sea. The results of this study stated that the peak of seasonal of chl- $a$ concentration and cooling SST also taken place in August, however the scale of chl- $a$ concentration and cooling SST increased (reduced) during the El Niño (La Niña). Furthermore, the prior study in the GoT by Setiawan and Habibi show that the monsoon system affects the seasonal of the chl- $a$ distribution. The chl- $a$ distribution increased in the boreal summer and peaked in August. In this study, we investigate monthly variation of chl- $a$ concentration in the GoT by analyzing satellite data. The present study shows the year-to-year variations of chl- $a$ blooming in the GoT and discusses their possible relationship to the climate mode events especially ENSO and IOD events.

\section{MATERIALS AND METHODS}

\section{Study area}

The GoT is situated on the northern side of the Sulawesi Island $\left(2^{\circ} \mathrm{N}-2^{\circ} \mathrm{S}\right.$ and $\left.120^{\circ} \mathrm{E}-126^{\circ} \mathrm{E}\right)$ (Figure 1). The unique topography of the GoT allows water exchange with the Maluku Sea, which is an important linking inflow from the Pacific Ocean to the Indian Ocean (Schneider 1998; Gordon 2005b). The unique topography of the GoT strongly suggest the dynamics of water exchange between the eastern (outside) and the western (inside) part of the GoT. Furthermore, the GoT has high marine biodiversity and significant endemic organism (Huffard et al. 2012).

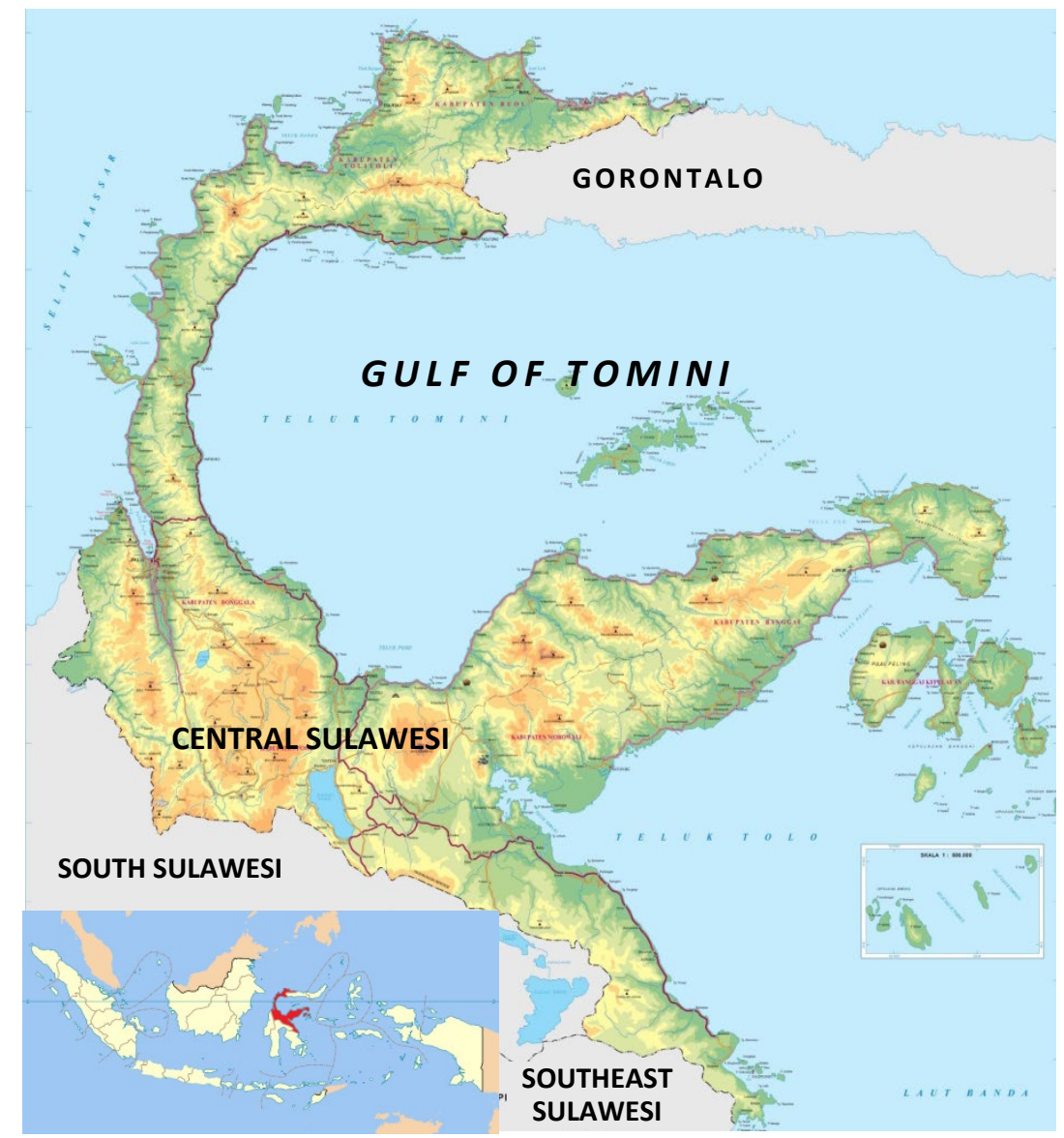

Figure 1. The study area in the Gulf of Tomini, Sulawesi, Indonesia 


\section{Surface chlorophyll- $a$}

Ocean color data were obtained from the Moderate Resolution Imaging Spectroradiometer (MODIS) on board of the Aqua. The data used in this study were the monthlyaveraged chl- $a$ concentration at $9 \mathrm{~km}$ spatial resolution from January 2003 to December 2015. The Unix-based SeaWiFS Data Analysis System (SeaDAS) version 6.4 was used to sub-sampling the ocean color data of the study region. Due to clouds interference of the satellite-retrieved chl- $a$ datasets have pixels with no data. Therefore, we reconstructed these data missing using empirical orthogonal function-based data interpolation (DINEOF) to produce cloud-free satellite chl- $a$ datasets (Alvera-Azcárate et al. 2007). Before applying the DINEOF, the time series of chl- $a$ data was reconstructed into a three-dimensional matrix, in which the first two dimensions were spatial dimensions (latitude and longitude), while the third dimension was time (number of months). Then, the missing values in each chl- $a$ data were set to not-a-number $(\mathrm{NaN})$.

\section{Sea surface temperature}

The sea surface temperature (SST) data were derived from the Advanced Very High-Resolution Radiometer (AVHRR) provided by the National Oceanographic and Atmospheric Administration (NOAA). These monthly Optimum Interpolations (OI) SST data have spatial resolution of $0.25^{\circ} \times 0.25^{\circ}$. We utilized the OI-SST data for a period from January 2003 to December 2015.

\section{Surface winds}

The wind data were obtained from the European Centre for Medium-Range Weather Forecasts (ECMWF) Operational Ocean Analysis/Reanalysis System (ORA S3). The data are global data with a horizontal resolution of $2.5^{\circ} \times 2.5^{\circ}$. Similarly, we used the data for a period extending from January 2003 to December 2015.

Monthly climatology of the chl- $a$, SST, and surface wind fields was calculated from the monthly time series over the period of January 2003-December 2015. Then, the anomaly fields for all variables were defined as deviations from their monthly climatological fields.

\section{RESULTS AND DISCUSSION}

\section{Seasonal variations}

The monthly climatological field of surface chl- $a$ in the GoT are presented in Figure 2. The most obvious feature in Figure 2 is that the inner part of the GoT is dominated by low chl- $a$ concentration throughout the year. Meanwhile, the concentration of chl- $a$ in the outer part revealed robust seasonal variation. High chl- $a$ concentrations ( $>0.3 \mathrm{mgm}-$ 3 ) were observed during boreal summer (July-September) and were mostly concentrated to a narrow zone along the coast near the eastern tip of the Central Sulawesi (Figure 2.G-I). The peak of chl- $a$ bloom occurred in August (Figure 2.H). Chl- $a$ concentrations in the entire GoT were lower $(<0.1 \mathrm{mg} \mathrm{m}-3)$ during boreal winter (DecemberFebruary) than those during boreal summer (Figure 2.L-B).
Figure 3 shows the monthly climatological fields of SST and surface wind vectors in the GoT. During boreal summer SST distribution in the GoT showed an east-west SST gradient, with low (relatively high) SST covers the eastern (western/central) part of the GoT (Figure 3.G-I). We suggest that the low SST observed in the region is associated with the southeasterly winds, which are favorable for upwelling. Note that the SST in the center of the GoT remained warm during boreal summer compared to that along the coasts and in the eastern part of the GoT. Seasonal vertical stratification analysis may be required to explore the dynamics underlying the mechanism of those two-contrasting spatial and temporal SST variations.

The monthly climatological field of surface winds revealed a prominent seasonal reversal of the monsoon wind (Figure 3). The southeasterly winds are observed during boreal summer (Figure 3.F-J) and the northwesterly winds appeared during boreal winter from December to March (Figure 3.L-C). We note that April/May and November are the transition seasons of monsoon as the wind gradually turned their direction. Note that the surface chl- $a$ concentrations increased (decreased) during boreal summer (winter) as the surface winds are favorable for upwelling (downwelling).

\section{Year-to-year variations}

In this section, year-to-year variation of chl- $a$ distribution is evaluated in term of the distribution of chl- $a$ anomalies. Note that the anomalous chl- $a$ concentration was computed as the deviation from the monthly climatological fields for the period of January 2003December 2015. We selected some years associated with coupled ocean-atmosphere modes in the tropical IndoPacific region, namely the El Niño/La Niña and the positive/negative Indian Ocean Dipole (IOD) events (Rao and Yamagata 2004; Horii et al. 2008; McPhaden 2008; Iskandar et al. 2013; 2014a; 2014b; 2017). The coupled ocean-atmosphere modes occurred repeatedly during January 2003-December 2015. Table 1 indicates the occurrence of El Niño/La Niña and positive/negative IOD events from 2003 to 2015 based on the Niño3.4 index and Dipole Mode Index (DMI). Note that Niño3.4 index was calculated as the averaged SST anomaly in the central equatorial Pacific $\left(5^{\circ} \mathrm{S}-5^{\circ} \mathrm{N}\right.$ and $\left.120^{\circ} \mathrm{W}-170^{\circ} \mathrm{W}\right)$ (McPhaden 2008). Whereas, the DMI was calculated as the SST gradient between the western tropical Indian Ocean $\left(10^{\circ} \mathrm{S}-10^{\circ} \mathrm{N}\right.$ and $\left.50^{\circ} \mathrm{E}-70^{\circ} \mathrm{E}\right)$ and the southeastern tropical Indian Ocean $\left(10^{\circ} \mathrm{S}-0^{\circ} \mathrm{N}\right.$ and $90^{\circ} \mathrm{E}-110^{\circ} \mathrm{E}$ ) (Saji et al. 1999). Based on Table 1, it is captured that the positive IOD events respective with the $\mathrm{El}$ Niño events in 2006/2007 and 2015/2016 and positive IOD with La Niña in 2007/2008, 2008/2009, and 2011/2012. Meanwhile, the negative IOD co-occurred with the La Niña events in 2005/2006 and 2010/2011. From Table 1 noticed that the phenomenon in 2009/2010 and 2003 is influenced by El Niño and positive IOD, respectively. Based on the Niño3.4 index and DMI, we found 4 El Niño events, 5 La Niña events, 7 positive IOD events, and 2 negative IOD events as shown in Table 1. 
Table 1. Classification of the El Niño/La Niña and IOD years from 2003-2015 based on the Niño3.4 index (McPhaden 2008) and the Dipole Mode Index (Saji et al. 1999)

\begin{tabular}{cccc}
\hline EI Niño & La Niña & Positive IOD & $\begin{array}{c}\text { Negative } \\
\text { IOD }\end{array}$ \\
\hline $2004 / 2005$, & $2005 / 2006$, & $2003,2006^{*}$, & 2005 and \\
$2006 / 2007$, & $2007 / 2008^{*}$, & 2007,2008, & $2010^{*}$ \\
$2009 / 2010$, & $2008 / 2009$, & 2011,2012, & \\
and & $\begin{array}{c}2010 / 2011^{*}, \\
\text { and } \\
2015 / 2016^{*}\end{array}$ & and $2015^{*}$ & \\
& $2011 / 2012$ & & \\
\hline
\end{tabular}

Note: Event with an asterisk symbol was classified as a strong event

Figure 4 shows the distribution of chl- $a$ anomalies during June-December from 2003 to 2015. Overall, the significant positive anomalies of the surface chl- $a$ first appeared over the eastern GoT. It is shown that the chl- $a$ concentration in the eastern GoT region is higher during El Niño events (positive anomaly of chl- $c$ concentration) than that during La Niña events (negative anomaly of chl- $a$ concentration). A remarkable feature was observed in 2015 when a strong El Niño event took place in the tropical Pacific, an anomalous chl- $a$ concentration was observed in the entire GoT and its surrounding region (Figure 4.M1M7). Note that the peak of chl- $a$ anomaly was observed at the end of development phase of the 2015/2016 El Niño event in September 2015 until the early peak phase of the event in October-November 2015 (Iskandar et al. 2017). The chl- $a$ concentration was rapidly reduced in December 2105 before the termination of the 2015/2016 El Niño event. The 2004/2005 El Niño event was also associated with high chl- $a$ concentration but it was only observed in the eastern part of the GoT (Figure 4.B1-B6). Meanwhile, high chl- $a$ concentration only revealed during the peak phase of the 2009/2010 El Niño event in NovemberDecember 2009 (Figure 4.G6-G7). High chl- $a$ concentration was also observed during positive IOD events in 2003 and 2006. However, the chl- $a$ concentration was higher and distributed across the GoT during the pure IOD event in 2003 (Rao and Yamagata 2004) than that during the positive IOD event co-occurred with weak El Niño event in 2006 (Horii et al. 2008). Interestingly, when the positive IOD event co-occurred with the Niña event in 2007 and 2011 (Iskandar et al. 2014a), chl- $a$ concentration in the GoT also increased, in particular during July-August 2007 (Figure 4.F2-F3) and August-September 2011 (Figure 4.I3-I4). Opposite situation was observed during La Niña and/or negative IOD events. Low chl- $a$ concentration was observed during strong La Niña and/or negative IOD events in 2010/2011 (Figure 4.H1-H7). We found a very low chl- $a$ concentration near the mouth of the GoT during July-September 2010 (Figures 4.H2-H4).

In order to evaluate the mechanism of chl- $a$ variations in the GoT, we explore the spatial and temporal variability of SST and wind anomalies during June-December for each year with particular emphasis on the occurrence of the El Niño/La Niña and positive/negative IOD events (Figure 5). This changing in the SST during the El-Niño and IOD events are found to be associated with related changes in the surface wind. The anomaly patterns show that high the chl- $a$ concentrations agree with lower the negative SST anomaly (Figure 5). Meanwhile, the results also consistently show that the low chl- $a$ concentrations coincide with the positive SST. The positive SST anomalies generated by the northeasterly wind anomalies have depressed the surface chl- $a$ concentration in the GoT and its vicinity. On the other hand, negative SST anomalies induced by the southeasterly wind anomalies were followed by the positive surface chl- $a$ anomaly. It is clearly shown that two opposite events, namely a strong La Niña event in 2010/2011 and a strong El Niño event in 2015/2016 have caused two contrasting oceanic and atmospheric conditions in the GoT (Figure 5.H and 5.M). the contrast results in strong La Niña event in 2010/2011 (Figure 5.H1-H6), strong northeasterly wind anomalies generated downward Ekman pumping leading to warm SST anomaly. This downward Ekman pumping caused downwelling that depressed surface chl- $a$ concentration. Meanwhile, strong southeasterly wind anomalies were observed during strong El Niño event in 2015/2016 leading to upward Ekman pumping (Figure 5.M1-M5). This upward Ekman pumping was associated with upwelling causing negative SST anomaly and enhancing surface chl- $a$ concentration. Similar mechanism was applied to other years but with smaller intensity.

\section{Discussion}

The GoT is located in the tropics and received high solar radiation that makes favorable conditions for photosynthesis of phytoplankton. Moreover, the GoT is semi-enclosed water and mesotrophic water type. All of these factors affect the variability of chl- $a$ concentration in the GoT. We have also presented the seasonal and interannual variation of the chl- $a$ concentration in the GoT by utilizing the remote sensing data.

In order to increase our understanding on cause of chl- $a$ distribution in the GoT, we used MODIS data to identify the seasonal and year-to-year variations of surface chl- $a$. The present study revealed a clear seasonality of the chl- $a$ distributions in the GoT associated with the seasonal monsoonal winds. During the southeast monsoon (boreal summer), the concentrations of chl- $a$ is higher in the eastern part of the GoT compared to the inner part. The evolution was developed in June-September and decayed in November. The parallel winds to the eastern coast of the Sulawesi Island may cause water transported offshore. The wind drift pushes the water offshore from the eastern side to the center of the GoT, inducing water upward in the coastal water of the Sulawesi leading to high surface chl- $a$ concentration. On the other hand, the northeast monsoon shows reversal surface wind and SST anomalies leading to decreasing surface chl- $a$ concentration in the GoT and its vicinity. Similar situation has been reported in the southern Makassar Strait, which also experiences reversal of monsoonal winds (Nababan et al. 2016). Note that high chl- $a$ concentration along the eastern Sulawesi coast might be due to supply of nutrients from the river runoff that discharge into the GoT (Subarsyah 2008; Habibi et al. 2010). This agrees with the previous study that shown higher TSS (Total Suspended Solid) and turbidity were 
observed in the western part of the GoT than in the center of the GoT during boreal summer (Setiawan and Habibi 2011). The southeast monsoon also exhibited the diverse low temperature of water mass in the eastern of the gulf toward the entire of the gulf. The high concentration of chl$a$ concentration matches concerning ITF path via Maluku Sea and peaks in boreal summer (June-August). The northeastern chl- $a$ concentration may indicate waters mass in the Maluku Sea increase cause the wind bring nutrient from the Pacific Ocean via the Maluku Sea to the Indian Ocean. The wind in the center of the gulf may also enhance the chl- $a$ concentration. Nevertheless, the northeast monsoon shows reversal temperature and chl- $a$ and can support the decreasing of chl- $a$ concentration. High chl- $a$ along the southern coast of Sulawesi Island may also be due to regional topography. It changed vector wind and transform the upwelling region because Ekman transport (Setiawan and Kawamura 2011).

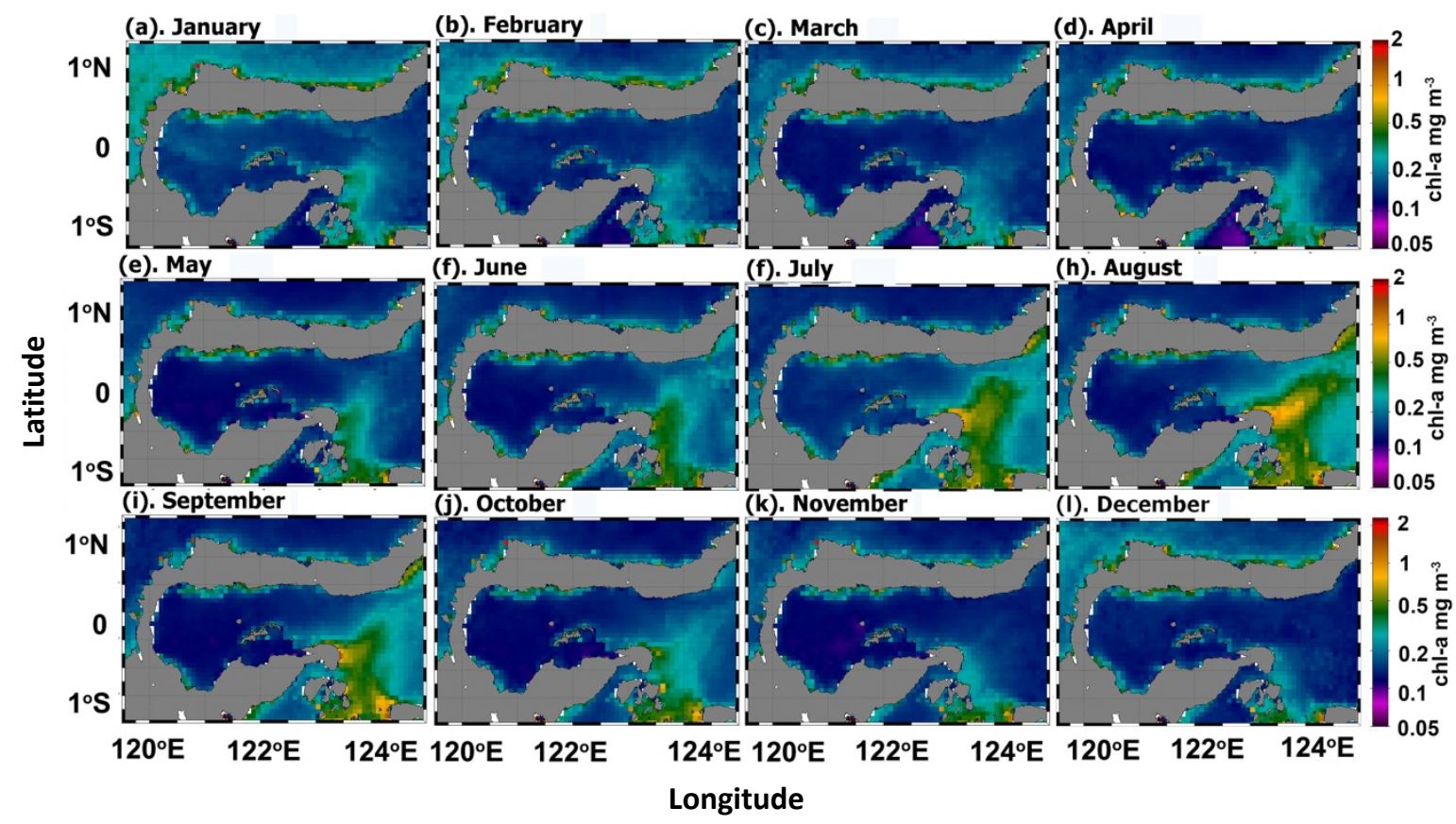

Figure 2. Monthly climatology of surface chl- $a$ concentration in in the Gulf of Tomini, Sulawesi, Indonesia
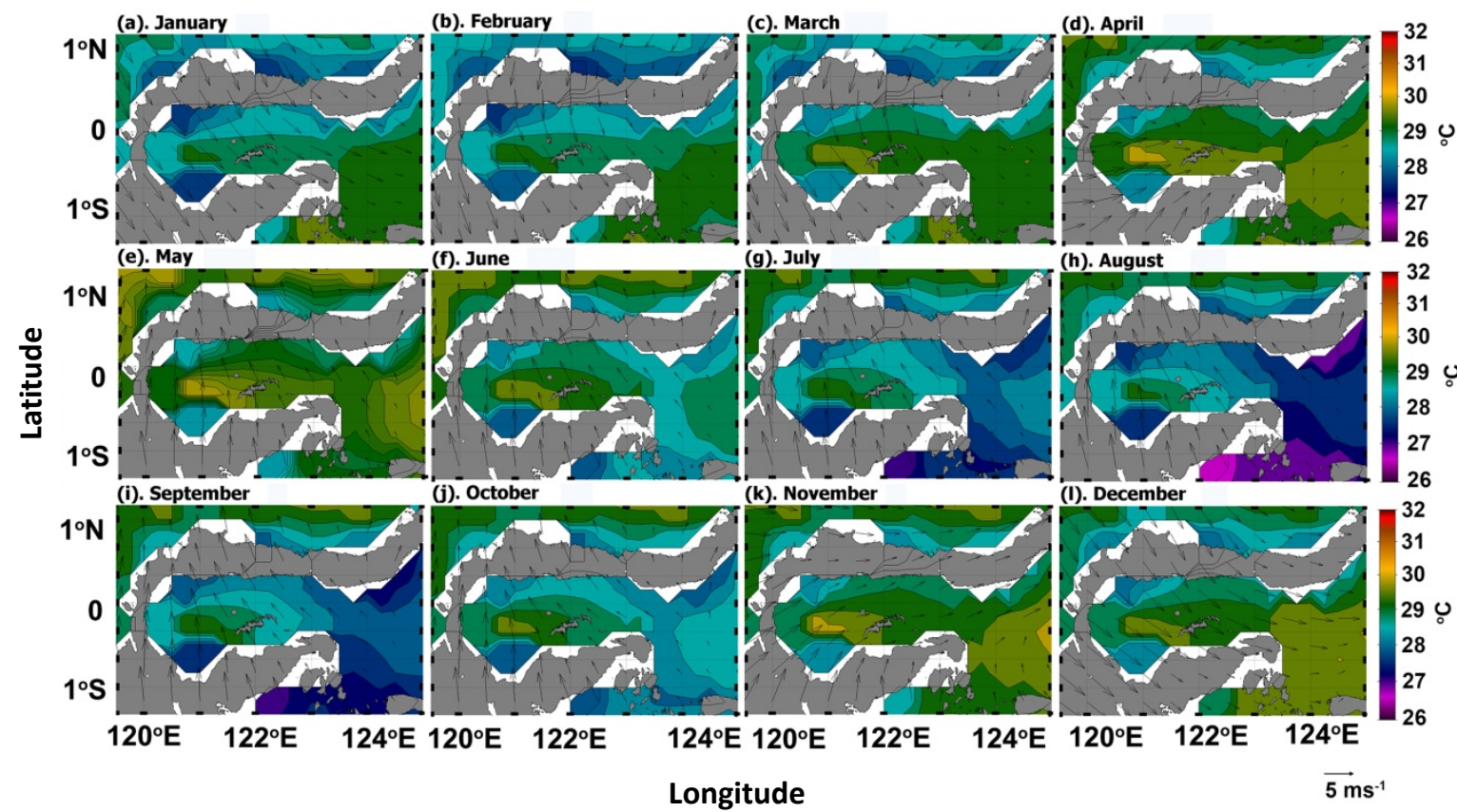

Figure 3. Monthly climatology of SST (shaded) and surface winds (vector) in the Gulf of Tomini, Sulawesi, Indonesia 


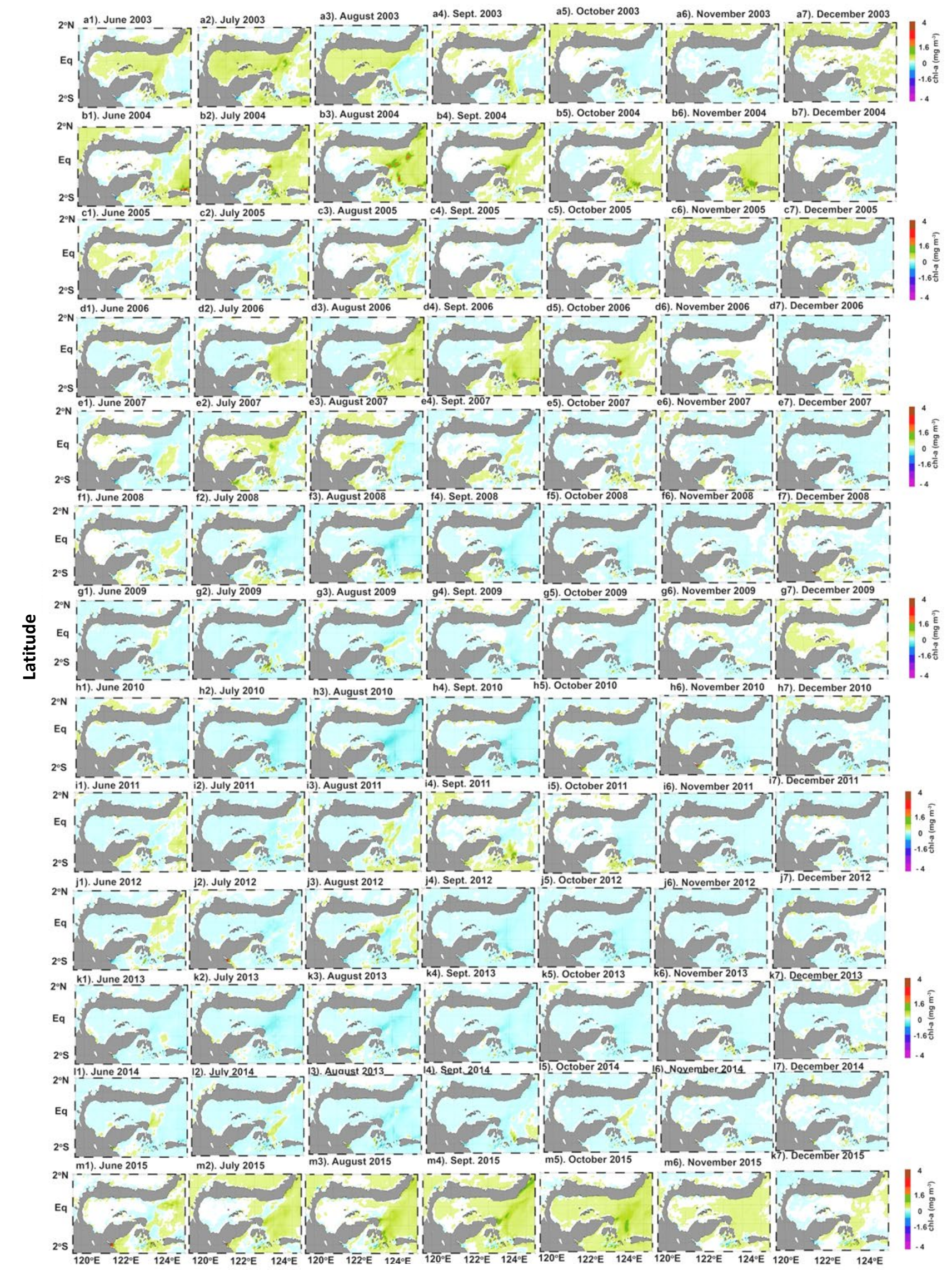

\section{Longitude}

Figure 4. The distribution of anomalous chl- $a$ concentration $\left(\mathrm{mg} \mathrm{m}^{-3}\right)$ during June-December from 2003 to 2015 in the Gulf of Tomini, Sulawesi, Indonesia 


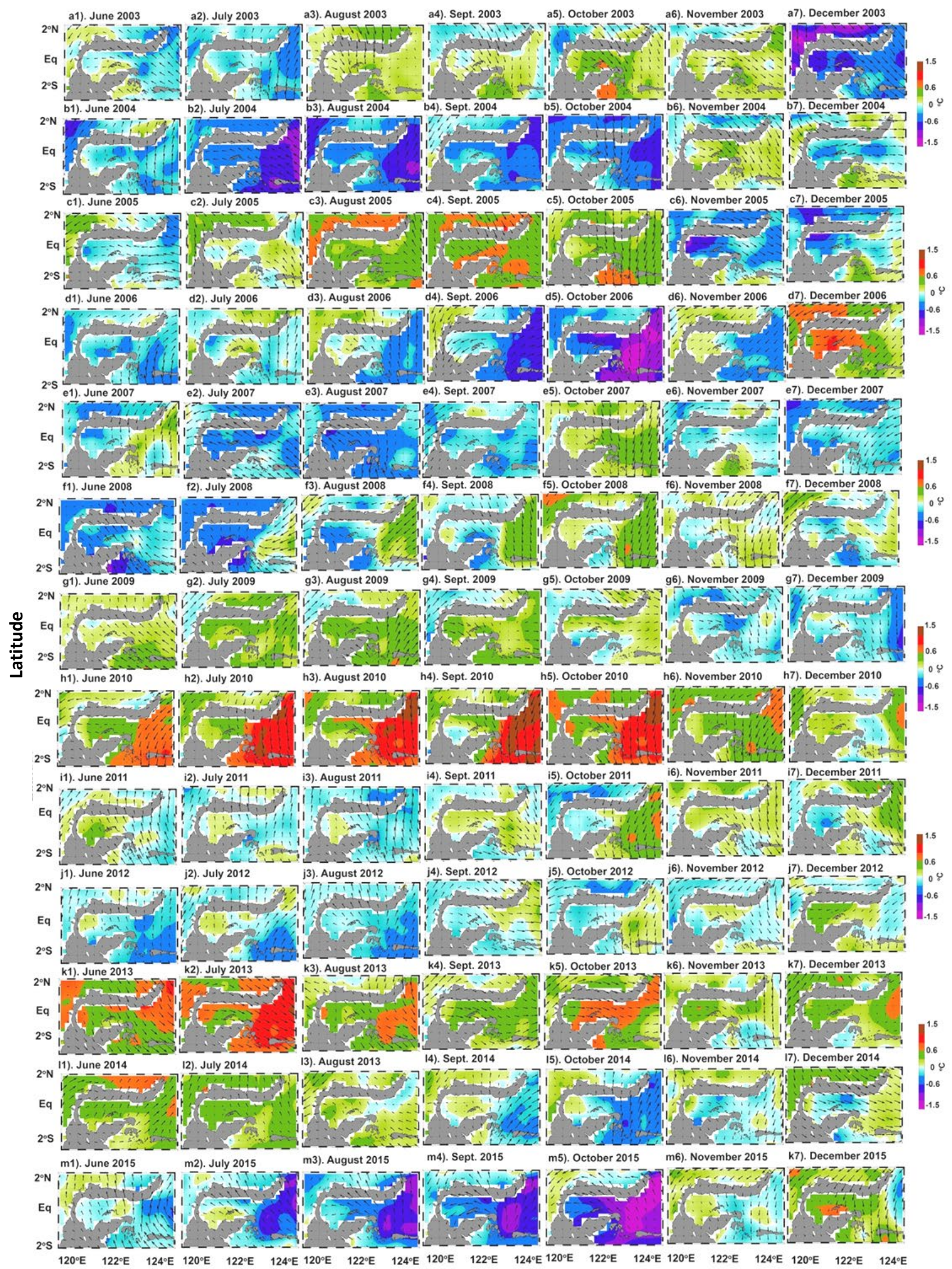

Longitude

Figure 5. The monthly anomaly of the SST (shaded) and surface winds (vector) during June-December from 2003 to 2015 in the Gulf of Tomini, Sulawesi, Indonesia 
Figure 4 shows the year-to-year spatial anomaly variations of the surface chl- $a$ in the GoT during its evolution. The year-to-year anomaly variation of the surface chl- $a$ concentration in the GoT was strongly linked to the coupled ocean-atmosphere mode in the tropical IndoPacific region, namely the El Niño/La Niña and positive/negative IOD events. This study revealed that high surface chl- $a$ concentration was observed during El Niño and/or positive IOD events. The appearance of effect phases of ENSO and IOD is obvious by evaluating the spatial patterns of chl- $a$ and SST anomaly during the ENSO/IOD events from climatology. During the El Niño and positive IOD events in the 2006 and 2015, the eastern GoT experienced the negative SST phase. The most striking feature was observed during the early evolution positive IOD phase of the positive IOD in June and decayed in October. While the El Niño event, the chl- $a$ concentration in waters is relatively higher in eastern gulf and uniform in the whole gulf. This condition was reverse during La Niña because of weak winds and large sea surface heating was well developed in this event. Enhanced surface chl- $a$ concentration during El Niño and/or positive IOD events was associated with upward Ekman pumping induced by the south-easterly wind anomalies. The situation was reversed during the Niña and/or negative IOD events in 2010. Meanwhile, the warmer SST anomalies were observed in the eastern of the GoT in the La Niña event started in June and terminated in December. Rarely anomaly climate event occurred in 2007 because consecutive with positive IOD and La Niña event (Behera et al. 2008). Its event shows that evolution of chl- $a$ concentration anomaly follows the negative SST pattern. In addition, Wirasatriya et al. (2017) find that the El Niño (La Niña) event clearly changed the increasing of chl- $a$ concentration and SST cooling in the mouth of Tomini Gulf and Bitung Peninsula (the Maluku Sea) and it does not change the area of high concentration and SST cooling.

Analysis indicates that the interannual variability of the total chl- $a$ is particularly influenced by the ENSO instead of the Indian Ocean Dipole. The finding also shows that the ENSO/IOD event also changed the period of increasing the chl- $a$ concentration. The surface wind-related the El Niño cycle was found to carry out much higher the ITF transport through the Indonesian Seas which was confirmed by previous studies ( $\mathrm{Hu}$ and Sprintall 2016). Meanwhile, it was also influenced by seasonal and interannual spatial variation of chl- $a$ in the GoT.

\section{ACKNOWLEDGEMENTS}

This research was supported by the PMDSU Scholarship funded the Ministry of Research, Technology and Higher Education, Indonesia. The last author is supported by the Ministry of Research, Technology and Higher Education, Indonesia through Penelitian Berbasis Kompetensi 2017 (No. 102/SP2H/LT/DRPM/IV/2017) and by the University of Sriwijaya through Hibah Unggulan Profesi 2017 (No. 987/UN9.3.1/PP/2017). Part of this study is supported by the Asia Pacific Network (APN) for
Global Change Research through a research project for the Climate Adaptation Framework (CAF2016-RR06-CMYSiswanto).

\section{REFERENCES}

Alvera-Azcárate A, Barth A, Beckers JM, Weisberg RH. 2007. Multivariate reconstruction of missing data in sea surface temperature, chlorophyll, and wind satellite fields. J Geophys Res Ocean 112: 1-11.

Asanuma I. 2003. Spatial distribution of phytoplankton along the Sunda Islands: The monsoon anomaly in 1998. J Geophys Res 108: 3202.

Behera SK, Luo JJ, Yamagata T. 2008. Unusual IOD event of 2007. Geophys Res Lett 35. DOI:10.1029/2008GL034122

Ffield A, Gordon AL. 1996. Tidal Mixing Signatures in the Indonesian Seas. J Phys Oceanogr 26, 1924-1937

Godfrey JS. 1996. The effect of the Indonesian throughflow on ocean circulation and heat exchange with the atmosphere: A review. J Geophys Res 101: 12217.

Gordon AL. 2005a. Indonesian Seas. Oceanogr. Indones Seas Their Throughflow 18: 14-27.

Gordon AL. 2005b. Oceanography of the Indonesian sea and their throughflow. Oceanography 18: 14-27.

Habibi A, Setiawan RY, Zuhdy AY. 2010. Wind-driven coastal upwelling along South of Sulawesi Island. Ilmu Kelaut. Indon J Mar Sci 15: 113-118.

Horii T, Hase H, Ueki I, Masumoto Y. 2008. Oceanic precondition and evolution of the 2006 Indian Ocean dipole. Geophys Res Lett 35: 1-6.

$\mathrm{Hu} \mathrm{S}$, Sprintall J. 2016. Interannual variability of the Indonesian Throughflow: The salinity effect. J Geophys Res Ocean Res 121: 2596-2615.

Huffard CL, Erdmann MV, Gunawan T. 2012. Geographic Priorities for Marine Biodiversity Conservation in Indonesia. Ministry of Marine Affairs and Fisheries and Marine Protected Areas Governance Program, Jakarta.

Iskandar I, Irfan M, Syamsuddin F. 2013. Why was the 2008 Indian Ocean Dipole a short-lived event? Ocean Sci J 48: 149-160.

Iskandar I, Mardiansyah W, Setiabudidaya D, Poerwono P, Kurniawati N, Saymsuddin F, Nagura M. 2014a. Equatorial oceanic waves and the evolution of 2007 Positive Indian Ocean Dipole. Terr Atmos Ocean Sci 25: 847-856.

Iskandar I, Masumoto Y, Mizuno K, Sasaki H, Affandi AK, Setiabudidaya D, Syamsuddin F. 2014b. Coherent intraseasonal oceanic variations in the eastern equatorial Indian Ocean and in the Lombok and Ombai Straits from observations and a high-resolution OGCM. J Geophys Res Ocean 119: 615-630.

Iskandar I, Rao SA, Tozuka T. 2009. Chlorophyll- $a$ bloom along the southern coasts of Java and Sumatra during 2006. Intl J Remote Sens 30: 663-671.

Iskandar I, Sasaki H, Sasai Y, Masumoto Y, Mizuno K. 2010. A numerical investigation of eddy-induced chlorophyll bloom in the southeastern tropical Indian Ocean during Indian Ocean Dipole-2006. Ocean Dyn 60: 731-742.

Iskandar I, Utari PA, Lestari DO, Sari QW, Khakim MYN, Yustian I, Dahlan Z. 2017. Evolution of 2015 / 2016 El Niño and its impact on Indonesia. AIP Conf Proc. DOI: 10.1063/1.4987095

Kusnida D, Subarsyah. 2008. Deep Sea Sediment Gravity Flow Deposits in Gulf of Tomini, Sulawesi. Indon J Geosci 3: 217-224.

Lee T, Fukumori I, Menemenlis D, Xing ZF, Fu LL. 2002. Effects of the Indonesian Throughflow on the Pacific and Indian oceans. J Phys Oceanogr 32: 1404-1429.

McPhaden MJ. 2008. Evolution of the 2006-2007 El Nino: interannual time scale dynamics. Adv Geosci 219-230.

Nababan B, Rosyadi N, Manurung D, Natih NM, Hakim R. 2016. The seasonal variability of sea surface temperature and chlorophyll- $a$ concentration in the South of Makassar Strait. Procedia Environ Sci 33: 583-599.

Qu T, Du Y, Strachan J, Meyers G, Slingo J. 2005. Sea surface temperature and its variability in the Indonesian Region. Oceanography 18: 50-61.

Rao SA, Yamagata T. 2004. Abrupt termination of Indian Ocean dipole events in response to intraseasonal disturbances. Geophys Res Lett 31. DOI: $10.1029 / 2004$ GL020842 
Saji NH, Goswami BN, Vinayachandran PN, Yamagata T. 1999. A dipole mode in the tropical Indian Ocean. Nature 401: 360-363.

Schneider N. 1998. The Indonesian Throughflow and the Global Climate System. J Clim 11: 676-689.

Setiawan RY, Habibi A. 2011. Satellite detection of summer chlorophyll$a$ bloom in the Gulf of Tomini. IEEE J Sel Top Appl Earth Obs Remote Sens 4: 944-948.

Setiawan RY, Kawamura H. 2011. Summertime Phytoplankton Bloom in the South Sulawesi Sea. IEEE J Sel Top Appl Earth Obs Remote Sens 4: $241-244$.

Sprintall J, Gordon AL, Koch-Larrouy A, Lee T, Potemra JT, Pujiana K, Wijffels SE. 2014a. The Indonesian seas and their role in the coupled ocean-climate system. Nat Geosci 7: 487-492.

Sprintall J, Revelard A. 2014b. The Indonesian Throughflow response to Indo-Pacific climate variability. J Geophys Res Ocean 119: 2843 2859.
Susanto RD, Moore II TS, Marra J. 2006. Ocean color variability in the Indonesian Seas during the SeaWiFS era. Geochemistry Geophys Geosystems 7: 1-16.

Trenberth KE. 1997. The Definition of El Niño. Bull Am Meteorol Soc 78: $2771-2777$.

Waworuntu JM, Fine RA, Olson DB, Gordon AL. 2000. Recipe for Banda Seawater. J Mar Res 58: 547-569.

Webster PJ, Moore AM, Loschnigg JP, Leben RR. 1999. Coupled oceanatmosphere dynamics in the Indian Ocean during 1997-98. Nature 401: 356-360.

Widodo J. 2004. Report of the Workshop on Development of a Management Plan for Tomini Bay Fisheries, Indonesia.

Wirasatriya A, Setiawan RY, Subardjo P. 2017. The Effect of ENSO on the variability of chlorophyll- $a$ and sea surface temperature in the Maluku Sea. IEEE J Sel Top Appl Earth Obs Remote Sens 10: 55135518 . 